\title{
Rational Use of Drugs Among Inpatients and Its Association with Health Literacy
}

\section{Hastalarda Akııı Illaç Kullanımı ve Sağık Okuryazarlığı ile llişkisi}

\author{
(D) Filiz Abacıgil ${ }^{1}$, (1) Selen Gürsoy Turan ${ }^{1}$, (1) Filiz Adana ${ }^{2}$, (D Pınar Okyay ${ }^{1}$, (1) Buket Demirci ${ }^{3}$ \\ ${ }^{1}$ Aydın Adnan Menderes University Faculty of Medicine, Department of Public Health, Aydın, Turkey \\ ${ }^{2}$ Aydın Adnan Menderes University Faculty of Nursery, Department of Public Health, Aydın, Turkey \\ ${ }^{3}$ Aydın Adnan Menderes University Faculty of Medicine, Department of Pharmacology, Aydın, Turkey
}

Keywords

Medication adherence, self medication, health literacy, Turkey

\author{
Anahtar Kelimeler \\ Tedaviye uyum, kendi kendine tedavi, sağlık \\ okuryazarlığı, Türkiye
}

Received/Geliş Tarihi : 17.05.2017

Accepted/Kabul Tarihi : 04.01.2018

doi:10.4274/meandros.galenos.2018.35119

Address for Correspondence/Yazışma Adresi: Filiz Abacıgil MD,

Aydın Adnan Menderes University Faculty of Medicine, Department of Public Health, Aydın, Turkey

Phone : +9053030014 41

E-mail : fergin@adu.edu.tr

ORCID ID: orcid.org/0000-0003-4291-0013

(C) Meandros Medical and Dental Journal, Published by Galenos Publishing House.

This is article distributed under the terms of the Creative Commons Attribution NonCommercial 4.0

International Licence (CC BY-NC 4.0).

\begin{abstract}
Objective: Rational use of drugs (RUD) plays a vital role in the success of the treatment process. Considering that use of medicines is also related with decision making mechanisms of individuals, RUD and health literacy levels should be considered together. The aim of this study is to determine the attitudes of patients related to RUD and its relationship with health literacy.

Materials and Methods: This cross-sectional analytical study was conducted on 361 patients hospitalized at a University Hospital carried out in Turkey. A rational usage of drug questionnaire and The Turkish health literacy survey questionnaire was used.

Results: It was found that $60.7 \%$ of patients kept leftover drugs to use later. Self medications with antibiotics were $32.6 \%$; regular vitamin intake was $31.7 \%$. From a total of 361 patients $\% 56.2$ of them reported that they stopped their medications when they felt better. The majority of the patients had insufficient/problematic health literacy level. Informing physicians about previously used medications/ health problems, informing healthcare professionals about food/drug allergies; use of medications for the adequate period of time, consulting to a physician when a side effect occurs, using drugs with physicians' recommendation increase, as health literacy level increases.

Conclusion: Improving health literacy level of the public can reduce selfmedication, improve adherence to therapy and so increase awareness of RUD.
\end{abstract}

Öz

Amaç: Akılcı ilaç kullanımı (AiK) tedavi sürecinin başarııında yaşamsal bir rol oynar. İlaç kullanımının, bireylerin karar verme mekanizmaları ile ilişkisi olduğu düşünüldüğünde, AiK ve sağlık okuryazarlığı düzeylerinin birlikte değerlendirilmesi gerekmektedir. Bu çalışmanın amacı hastaların akılcı ilaç kullanım ile ilişkili tutumlarını ve bunun sağlık okuryazarlığı ile ilişkisini değerlendirmektir.

Gereç ve Yöntemler: Bu kesitsel tipteki çalışma Türkiye'de bir üniversite hastanesinde yatan 361 hasta üzerinde gerçekleştirilmiştir. Akılcı ilaç kullanım anketi ile Türkiye sağlık okuryazarlığı araştırması anketi kullanılmışıı. 
Bulgular: Hastaların \%60,7'si daha sonra kullanmak üzere ilaçları saklamaktadır. Antibiyotiklerle kendi kendine tedavi \%32,6; düzenli vitamin alımı \%31,7'dir. Üç yüz altmış bir hastadan \%56,2'si kendilerini iyi hissettiklerinde tedavilerini sonlandırdıklarını belirtmiştir. Hastaların çoğunun yetersiz/problemli düzeyde sağlık okuryazarlığı düzeyi vardır. Daha önce kullanılan tedaviler/sağlık sorunları konusunda hekimleri bilgilendirme durumu, sağlık personelini gıda/ilaç allerjileri konusunda bilgilendirme, verilen tedavilere yeterli süre devam etme, herhangi bir yan etki olduğunda hekime danışma, hekimlerin önerileri doğrultusunda ilaç kullanma durumları, bireylerin sağlık okuryazarlığı düzeyi arttıkça artmaktadır.

Sonuç: Halkın sağlık okuryazarlığı düzeyinin geliştirilmesi, kendi kendine tedaviyi azaltır, tedavilere uyumu artırır ve dolayısı ile Aik ile ilgili farkındalığı artırır.

\section{Introduction}

In 1985, during the conference of experts on rational use of drugs (RUD) in Nairobi, held by the World Health Organization (WHO), RUD was defined as; "patients receive medications appropriate to their clinical needs, in doses that meet their own individual requirements, for an adequate period of time and at the lowest cost to them and their community" (1). Prescription of incorrect, unnecessary medications or medications that are not in compliance with essential drugs list or updated guidelines and use of high priced medicines cause many problems in varying degrees worldwide $(2,3)$. WHO estimates that more than half of all medicines are prescribed, dispensed or sold inappropriately, and that half of all patients fail to take them correctly (4). From an individual point of view, habits for medication use are affected by physicians' recommendations of as well as the individual's sociodemographic and social status (5).

Prescription indicators, patient treatment indicators and healthcare unit indicators can be used to measure RUD (6). Additionally, most of the studies on RUD reviewed analysis of prescriptions and channels through which patients supply their medicines. Although irRUD is a major problem in developing countries, limited number of studies were found describing reasons for RUD (7-9).

Although Turkey is one of the first countries to have an infrastructure for RUD, many local and nationwide studies have found that the public is not sufficiently informed about RUD and does not follow RUD principles $(10,11)$. When a person gets sick, he/ she can use the already available drugs at home based on their previous experience with similar symptoms or ask drugs from friends or directly buy from the pharmacy and use such drugs in doses and time periods different from those that a physician would recommend $(5,10,12,13)$. Such approaches can lead to serious medical consequences.
In addition to socio-cultural, economic and regulatory mechanisms, RUD is closely related with education and health literacy level. Health literacy can be defined as, "individual's knowledge, motivation and competence to access, understand, appraise and apply information to prevent disease and promote health in daily life" (14). Low health literacy is shown to have a negative effect on patient adherence to medical treatment and management of diseases, lead to insufficient knowledge about diseases, and thus, is associated with higher hospitalization, morbidity and premature death (15). At this point, RUD and health literacy should be considered together. Decision makers can use RUD rates as an evaluation criteria to determine the effectiveness of the actions improving the health literacy levels. The aim of this study is to determine the habits of patients related to RUD and its relationship with health literacy.

\section{Materials and Methods}

This cross-sectional study was conducted on patients who were hospitalized at Aydın Adnan Menderes University Hospital between 7-14 September 2015. The Hospital is in the western Turkey with 533 beds. For the inclusion criteria of the study, participants who were 18 years and older and had stable conditions related with their health status were included. When intensive care patients, pediatric service patients and patients in isolation were excluded, 361 patients met the inclusion criterias and all target population was reached. Ethical approval was obtained from Ethical Committe of Aydın Adnan Menderes University (2015/645).

A semi-structured questionnaire form was used to collect data from patients by face-to-face interviews. The questionnaire form consisted of three major sections: 1) Demographics 2) RUD questionnaire 3) Turkish health literacy survey questionnaire (TSOY-32). 
Demographic questionnaire included questions about patients' age, sex, education, job, type of residence and income level. RUD questionnaire was developed by the Turkish Medicines and Medical Devices Agency for inpatients and consisted of 29 questions. The questions are about storage conditions for drugs, leftover/unused drugs, decisions to use drugs, side effects, information sources and etc.

TSOY-32 was developed by a Turkish consortium (2016) consisting of academicians and specialists from the Turkish Ministry of Health. Its conceptual framework was based on The European Health Literacy Survey Questionnaire (Q47). Crohnbach's alfa level of the scale was 0.927 . It is a 4 point likert type questionnaire with responses ranging from very easy (1) to very difficult (4). The lowest score is 32 and the highest is 128 . Total scores are standardized to be in between 0 and 50 . Four levels of health literacy was defined as; 0-25 for "inadequate", >25-33 for "problematic", >33-42 for "sufficient" and >42-50 for "excellent" as in the European Survey (16).

The data was analysed with software of SPSS 17.0 version. Normality distribution of continuous data was analysed with histogram and the Kolmogorov-Smirnov test. After examining the normality of distributions of the responses, descriptive statistics were presented as means \pm standard deviation (minimum-maximum) for continuous variables and as percentages for the categorical variables. In order to make comparisons between RUD and health literacy levels (because levels of health literacy is an ordinal type variable), chi-square test for trend was used. Type-1 error $(\alpha)$ level was assumed as "0.05".

\section{Results}

The mean age of the patients was $48.2 \pm 16.7$ (1887) years and $52.5 \%$ of them were female; $55.9 \%$ had an educational level of primary school or less; $19 \%$ had university degrees.

Regarding the habits of patients for medication use; $60.7 \%$ of the patients reported that they kept leftover drugs at home to use later, $31.2 \%$ had 6 or more packages of medications at home, $43.4 \%$ reported that they could dispose medications without even opening the package. Only half of the patients kept drugs in a cool and dry place at room temperature. On the other hand $68.0 \%$ of them stored drugs that require cold chain storage, on refrigerator door bins.
In case of using a leftover drug at home, 91.5\% of the patients reported that they checked whether the drug was appropriate for their health problems. Only $45.5 \%$ of them declaired that they consulted to a physician while using them. One forth of the patients reported that they could request for prescription medications without being sick such as; analgesics (62.3\%), antibiotics (10.4\%), flu drugs (9.4\%), vitamins (2.8\%), medications for stomach problems $(2.8 \%)$, eye drops (1.9\%) and others (allergy drugs etc). On the other hand, almost half of the patients (44.5\%) reported that they might not buy their prescribed drugs. From 361 patients, $20.8 \%$ of them reported that they could get medical advices from relatives/ friends and $23.6 \%$ of them said that they could give drug recommendations to individuals with similar complaints.

The majority of the patients ( $85.1 \%$ ) declaired that they visited a physician when they felt sick but $56.2 \%$ reported that they stopped their medications when they felt better. From 361 patients, self medication with antibiotics were $32.6 \%$, regular vitamin intake were $31.7 \%$; and adverticed medicinal drug intake were $14.2 \%$. Furthermore $59.8 \%$ of the participants believed that injectable medications were more effective.

Most of the patients (79.7\%) gave "physicians/ prospectuses" as their sources of information for medications and only $47.2 \%$ reported that they were informed about which food could be taken with the drugs they used. $71.6 \%$ of the patients reported that they informed healthcare personnel about their food/drug allergies and $86.1 \%$ informed about their previous medications/healthcare problems before their medical examinations. Distribution of some of the parameters of RUD were given in Table 1.

Regarding the definition and frequency of reading the prospectuses; $42.3 \%$ of the patients gave a correct definition and only one third of them (35.7\%) reported that they "always" read prospectuses. From 361 patients, $30.9 \%$ of them expressed their wish to get an education on RUD.

Health literacy levels of the participants were as following; $48.6 \%$ was insufficient, $36.5 \%$ was problematic, $10.4 \%$ was sufficient and $4.5 \%$ was excellent. In most of the parameters related with RUD in this study, appropriate habits were seen with the increasing level of health literacy. 
Table 1. Distribution of some of the parameters of rational use of drugs

RUD questionnaire

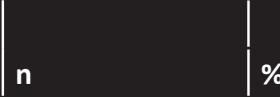

Consumin leftover drugs from previous treatments

Keeping them for further use as necessary

Giving them to a healthcare institution

Unused or leftover drugs at home

None or 1-5 packages**

6 packages and over

\begin{tabular}{|l|l|}
\hline 216 & 60.7 \\
\hline 140 & 39.3 \\
\hline & \\
\hline 245 & 68.8 \\
\hline 111 & 31.2 \\
\hline
\end{tabular}

Number of disposed unopened packages of medications that are expired

None**

At least one box

\begin{tabular}{|l|l|}
\hline 201 & 56.6 \\
\hline 154 & 43.4
\end{tabular}

Storage place of drugs for which no storage condition is specified

At room temperature, in a clean and dry place**

Fridge/freezer/deep freeze

\begin{tabular}{|l|l|}
\hline 186 & 52.2 \\
\hline 170 & 47.8 \\
\hline
\end{tabular}

Storage place of drugs for which cold chain management is specified

Refrigerator door bin**

Fridge/freezer/deep freeze

\begin{tabular}{|l|l|}
\hline 114 & 32.0 \\
\hline
\end{tabular}

\begin{tabular}{|l|l|}
\hline 242 & 68.0
\end{tabular}

Considerations when using leftover/unused drugs available at home

Looking for the appropriateness to illness/expiration date**

Pay no attention

\begin{tabular}{|l|l|}
\hline 325 & 91.5 \\
\hline 30 & 8.5 \\
\hline
\end{tabular}

Source of information in case of a leftover drug had been using at home

\begin{tabular}{|l|l|l}
\hline Physician** & 162 & 45.5 \\
\hline Person & 194 & 54.5
\end{tabular}

Person other than physicians

Requesting prescription drugs without being sick

\begin{tabular}{|l|l|l}
\hline Yes & 90 & 25.4 \\
\hline No** & 264 & 74.6
\end{tabular}

Requesting prescription of drugs based on recommendations of relatives/friends

Yes

No**

74

\begin{tabular}{|l|l}
74 & 20.8 \\
\hline 281 & 79.2
\end{tabular}

Not buying drugs from pharmacies although they were prescribed

I do not

I do*

\begin{tabular}{|l|l|}
\hline 155 & 44.5 \\
\hline 193 & 55.5
\end{tabular}

First person to consult for health problems

Physician**

Other

303

53

85.1

Recommending drugs to people who have similar complaints

Yes

No**

\begin{tabular}{|l|l|}
\hline 84 & 23.6 \\
\hline 272 & 76.4
\end{tabular}

Informing the physician about previously used medications/health problems

Yes**

No

286

86.1

The period in which prescribed drugs are taken

For the recommended period**

156 
Table 1. continued

\begin{tabular}{|c|c|c|}
\hline Until symptoms subside & 200 & 56.2 \\
\hline \multicolumn{3}{|c|}{ Self medication with antibiotics for flu-like symptoms } \\
\hline No** & 240 & 67.4 \\
\hline Yes & 116 & 32.6 \\
\hline \multicolumn{3}{|c|}{ Regular use of vitamin/mineral supplements } \\
\hline Yes & 113 & 31.7 \\
\hline No** & 243 & 68.3 \\
\hline \multicolumn{3}{|c|}{ Sources of information for medication use and side effects } \\
\hline Physician/prospectuses** & 283 & 79.7 \\
\hline Relatives/friends etc. & 72 & 20.3 \\
\hline \multicolumn{3}{|c|}{ Consulting to a physician when a drug has caused side effects } \\
\hline Yes** & 271 & 76.1 \\
\hline No & 85 & 23.9 \\
\hline \multicolumn{3}{|c|}{ Use of advertised medical products for treatment } \\
\hline No or after consulting to a physician** & 302 & 85.8 \\
\hline Yes & 50 & 14.2 \\
\hline \multicolumn{3}{|c|}{ Informing healthcare professional about any food or dug allergies } \\
\hline Yes** & 255 & 71.6 \\
\hline No & 101 & 28.4 \\
\hline \multicolumn{3}{|c|}{ Taking drugs without any medical examination } \\
\hline Yes & 124 & 34.9 \\
\hline No** & 231 & 65.1 \\
\hline
\end{tabular}

\begin{tabular}{|c|c|c|c|c|c|c|}
\hline \multirow[t]{2}{*}{ RUD questionnaire } & \multicolumn{6}{|c|}{ Health literacy levels* } \\
\hline & Insufficient & Problematic & Sufficient & Excellent & $x^{2}$ & $\mathrm{p}$ \\
\hline \multicolumn{7}{|c|}{ Consumin leftover drugs from previous treatments } \\
\hline Keeping them for further use as necessary & 59.5 & 63.1 & 62.2 & 50.0 & 0.014 & 0.906 \\
\hline Giving them to a healthcare institution & 40.5 & 36.9 & 37.8 & 50.0 & & \\
\hline \multicolumn{7}{|l|}{ Unused or leftover drugs at home } \\
\hline None or 1-5 packages** & 68.2 & 69.2 & 73.0 & 62.5 & 0.006 & 0.937 \\
\hline 6 packages and over & 31.8 & 30.8 & 27.0 & 37.5 & & \\
\hline \multicolumn{7}{|c|}{ Number of disposed unopened packages of medications that are expired } \\
\hline None** & 53.2 & 60.5 & 56.8 & 62.5 & 1.036 & 0.309 \\
\hline At least one box & 46.8 & 39.5 & 43.2 & 37.5 & & \\
\hline \multicolumn{7}{|c|}{ Storage place of drugs for which no storage condition is specified } \\
\hline $\begin{array}{l}\text { At room temperature, in a clean and dry } \\
\text { place** }\end{array}$ & 46.8 & 54.6 & 73.0 & 43.8 & 3.372 & 0.066 \\
\hline Fridge/freezer/deep freeze & 53.2 & 45.4 & 27.0 & 56.3 & & \\
\hline \multicolumn{7}{|c|}{ Storage place of drugs for which cold chain management is specified } \\
\hline Refrigerator door bin** & 37.0 & 27.7 & 29.7 & 18.8 & 3.528 & 0.066 \\
\hline
\end{tabular}


Table 2. continued

\begin{tabular}{|c|c|c|c|c|c|c|}
\hline Fridge/freezer/deep freeze & 63.0 & 72.3 & 70.3 & 81.3 & & \\
\hline \multicolumn{7}{|c|}{ Considerations when using leftover/unused drugs available at home } \\
\hline $\begin{array}{l}\text { Looking for the appropriateness to illness/ } \\
\text { expiration date** }\end{array}$ & 89.6 & 93.0 & 97.3 & 87.5 & 3.135 & 0.333 \\
\hline Pay no attention & 10.4 & 7.0 & 2.7 & 12.5 & & \\
\hline \multicolumn{7}{|c|}{ Source of information in case of a leftover drug had been using at home } \\
\hline Physician** & 44.5 & 44.6 & 48.6 & 56.3 & 0.661 & 0.416 \\
\hline Person other than physicians & 55.5 & 55.4 & 51.4 & 43.8 & & \\
\hline \multicolumn{7}{|c|}{ Requesting prescription drugs without being sick } \\
\hline Yes & 27.7 & 24.6 & 22.9 & 12.5 & 1.793 & 0.181 \\
\hline No** & 72.3 & 75.4 & 77.1 & 87.5 & & \\
\hline \multicolumn{7}{|l|}{$\begin{array}{l}\text { Requesting prescription of drugs based on } \\
\text { recommendations of relatives/friends }\end{array}$} \\
\hline Yes & 27.7 & 16.3 & 10.8 & 6.3 & 10.248 & 0.001 \\
\hline No** & 72.3 & 83.7 & 89.2 & 93.8 & & \\
\hline \multicolumn{7}{|c|}{ Not buying drugs from pharmacies although they were prescribed } \\
\hline I do not & 52.7 & 55.8 & 56.8 & 80.0 & 2.664 & 0.103 \\
\hline l do* & 47.3 & 44.2 & 43.2 & 20.0 & & \\
\hline \multicolumn{7}{|l|}{ First person to consult for health problems } \\
\hline Physician** & 82.7 & 85.4 & 91.9 & 93.8 & 2.926 & 0.087 \\
\hline Other & 17.3 & 14.6 & 8.1 & 6.3 & & \\
\hline \multicolumn{7}{|c|}{ Recommending drugs to people who have similar complaints } \\
\hline Yes & 23.1 & 26.2 & 18.9 & 18.8 & 1.151 & 0.711 \\
\hline No** & 76.9 & 73.8 & 81.1 & 81.3 & & \\
\hline \multicolumn{7}{|c|}{ Informing the physician about previously used medications/ health problems } \\
\hline Yes** & 80.5 & 88.5 & 97.3 & 93.3 & 8.176 & 0.004 \\
\hline No & 19.5 & 11.1 & 2.7 & 6.7 & & \\
\hline \multicolumn{7}{|c|}{ The period in which prescribed drugs are taken } \\
\hline For the recommended period** & 35.3 & 47.7 & 51.4 & 87.5 & 16.575 & $<0.001$ \\
\hline Until symptoms subside & 64.7 & 52.3 & 48.6 & 12.5 & & \\
\hline \multicolumn{7}{|c|}{ Self medication with antibiotics for flu-like symptoms } \\
\hline No** & 64.2 & 70.0 & 67.6 & 81.3 & 1.905 & 0.167 \\
\hline Yes & 35.8 & 30.0 & 32.4 & 18.8 & & \\
\hline \multicolumn{7}{|l|}{ Regular use of vitamin/mineral supplements } \\
\hline Yes & 39.3 & 20.8 & 40.5 & 18.8 & 3.697 & 0.055 \\
\hline No** & 60.7 & 79.2 & 59.5 & 81.3 & & \\
\hline \multicolumn{7}{|c|}{ Sources of information for medication use and side effects } \\
\hline Physician/prospectuses** & 75.7 & 81.4 & 91.9 & 81.3 & 5.347 & 0.058 \\
\hline Relatives/friends etc. & 24.3 & 18.6 & 8.1 & 18.8 & & \\
\hline \multicolumn{7}{|c|}{ Consulting to a physician when a drug has caused side effects } \\
\hline Yes** & 68.2 & 80.0 & 91.9 & 93.8 & 14.266 & $<0.001$ \\
\hline No & 31.8 & 20.0 & 8.1 & 6.3 & & \\
\hline
\end{tabular}


Table 2. continued

\begin{tabular}{|l|l|l|l|l|l|l|l|}
\hline Use of advertised medical products for treatment \\
\hline No or after consulting to a physician** & 77.9 & 93.0 & 91.7 & 100.0 & 13.875 & $<0.001$ \\
\hline Yes & 22.1 & 7.0 & 8.3 & - & & \\
\hline Informing healthcare professional about any food or drug allergies & 63.6 & 75.4 & 86.5 & 93.8 & 14.139 & $<0.001$ \\
\hline Yes** & 36.4 & 24.6 & 13.5 & 6.3 & & \\
\hline No & & & & & \\
\hline Taking drugs without any medical examination & 32.0 & 38.5 & 43.2 & 18.8 & 4.341 & 0.689 \\
\hline Yes & 68.0 & 61.5 & 56.8 & 81.3 & \\
\hline No** & 6 & & \\
\hline $\begin{array}{l}\text { RUD: Rational use of drugs, *percentage of the column, Answers marked with ** refer to positive attitudes about rational use of } \\
\text { drugs }\end{array}$
\end{tabular}

Statistically significant parameters were as; requiring prescriptions advised by relatives/friends, using of advertised medicinal products without prescription, informing the physician about the medications being used or health problems/allergies; compliance to period of time while using drugs and consulting to a physician when a side effect occured. With the increasing level of health literacy, requesting prescription of drugs based on recommendation of relatives/friends and using products advertised in the media decreased. Informing physicians about previously used medications/health problems, informing healthcare professionals about food/drug allergies; use of medications for the adequate period of time, consulting to a physician when a side effect occurs, increase as health literacy level increases $(p<0.05)$. Distribution of some of the parameters of RUD according to health literacy levels was given in Table 2.

\section{Discussion}

RUD is related with patients, physicians, medicine supply systems under the control of the healthcare industry, regulations, lack of knowledge about drugs and a combination of all these factors. Due to ageing of societies worldwide, use of medicines is expected to increase more in coming decades leading to an excessive burden on them. This increase in medication use compels people to increase their health literacy level i.e. while using medicine correctly and improving their decision making skills. Therefore RUD and health literacy should be considered together and play an important role when developing relevant policies. This study specifically focused on patients' RUD and found that irRUD was an important problem and it was related with health literacy.

Regarding medication use habits of the patients, more than half of them (60.7\%) reported that they kept leftover drugs at home and almost half of them declaired that they sometimes had to discard medications without even opening them. A study conducted by Göçgeldi et al. (13) in Ankara reported similar results as keeping leftover drugs at home $50.0 \%$. In another study conducted in the same city, $61.2 \%$ of the study population reported that they kept leftover drugs at home, $26.8 \%$ reported that they disposed them as home waste, $11.2 \%$ reported that they gave them to relatives/friends, and $9.6 \%$ reported that they gave such drugs to the community clinics (17). In a study conducted in Malaysia, 9.1\% of the participants reported that they gave leftover antibiotics to other family members when they got sick (18). The results of these studies show that people tend to keep leftover drugs at home and have inappropriate habits for the disposal.

Regarding storage of the drugs that should be stored at room temperature, more than half of the participants stored their drugs in appropriate conditions however this percentage drops to $30 \%$ when it comes to drugs that require a cold chain. A study conducted by Ilhan et al. (5) reported that most of unused drugs (60\%) were stored in fridges. It is very important that drugs should be stored as instructed as recommended by the physician in order to maintain their mechanisms of action. Otherwise it 
should be remembered that drugs can cause harmfull effects instead of curing diseases.

Bilgili et al (17) reported that in case of using leftover drugs at home, $43.2 \%$ of study participants reported that they paid attention to expiration dates; $31.1 \%$ of them checked whether the drug was suitable for their condition, $8 \%$ checked that the package was intact and $1.8 \%$ reported they paid attention to none of the above. In another study from Turkey declaired that the percentage of people checking the expiration date was $80.2 \%(14)$, and in the Malaysian study this was $92.2 \%$ (18). In our study the percentage of patients who reported that they did not check anything was $8.5 \%$, findings of other responces were similar. In case of using a leftover drug at home, $45.5 \%$ of our study group reported that they would consult to a physician, whereas this rate was $72.8 \%$ in a study conducted in Ankara (17). Reasons for this difference can be the fact that our study sampling consisted of inpatients, were using medication frequently, were presenting to healthcare institutions more often and therefore had more tendency to self-medication.

$25.4 \%$ of the patients in our study reported that they could request drugs without being sick and the three most common prescribed drugs were analgesics (62.3\%); antibiotics (10.4\%) and flu drugs (9.4\%). In a study conducted in Malaysia, it was found as $15 \%$ (19). Illhan et al. (5) reported that the percentage of people who kept medications at home was $78.6 \%$ and $40 \%$ of such medications were analgesics, $19 \%$ were flu drugs, $15 \%$ were for stomach problems and $14 \%$ were antibiotics. The percentage of people who use drugs without consulting to a physician was $76.4 \%$ in Manisa and $71.5 \%$ in Ankara and most of these drugs were analgesics which is similar to our study $(7,14)$. In a study conducted in adolescents in Brazil, self medication was found to be $52.6 \%$ (19). In our study the percentage of participants who regularly took vitamin and mineral supplements was $31.7 \%$ whereas in a study conducted in Yemen it was found to be $11.2 \%$ (7). The reason why this percentage was higher can be explained as vitamin and mineral supplements are sold as over the counter products both in pharmacies and other stores in Turkey and people tend to use such supplements without any recommendation from physicians.

In our study, $20.8 \%$ of the patients reported that they could have prescriptions based on recommendations of relatives/friends. This rate was $45 \%$ in Ankara (5). Different study groups might explain the differences in results.

As in many developing countries, irrational use of antibiotics is also an important problem in Turkey. $32.6 \%$ of the patients in our study reported that they used self-medication with antibiotics for flu-like symptoms. Nayir et al. (11) reported that the rate of self-medication was $58.9 \%$ and self administered antibiotics was $29.4 \%$ in Elazığ, Turkey. Self medication with antibiotics was reported as $70 \%$ from senior university students in Ghana (20), and in a Malaysian study, antibiotics used without consulting to a physician for flu-like symptoms was $7.6 \%$. However $47 \%$ of the individuals reported that they could request antibiotic prescription from physicians for such a condition (18). In a study conducted in Trinidad and Tobago $20 \%$ of the participants obtained antibiotics drugs without prescription (21). In a Palestine study, $85.9 \%$ of participants thought that borrowing and using antibiotics from relatives/friends was not a good behavior and $67.7 \%$ thought that taking antibiotics without prescription was incorrect (22). In countries where access to medications is relatively easy and sales of medications without prescription is possible drugs are not used rationally. At this point, regulatory authorities should develop and implement necessary regulations and make regular controls to determine whether such regulations are complied with and use enforcement as necessary. Many studies on RUD indicate to a widespread misunderstanding and misuse of drugs among consumers, distributor and physicians $(10,11,18)$. One of the inappropriate habit is to stop using medications when complaints are resolved. In a study conducted in Malaysia 37\% of the participants reported that they stopped using antibiotics when their complaints were resolved (18) and in our study this percentage was $56.2 \%$. In the Palestine study, one third of the participants reported that they could stop taking antibiotics when they felt better, in a study conducted in senior university students who could be described as a higher group of class in the society in Ghana, use of antibiotics for adequate period was found as $54 \%(20,22)$.

Both in this study and in various studies in the literature the most frequently used information sources about drugs are physicians and other healthcare professionals $(5,22)$. It is important to 
explain medical information in a clear, understandable language until it is fully understood. But another thing which is as important as this, is to have a sufficient level of health literacy. Although healthcare consumers receive the treatments recommended by healthcare professions, the factor which determines medication use eventually, is the decision making mechanisms of individuals (5). This study found that as the health literacy level increases, some parameters of RUD also increase. Requesting prescription for drugs without a physician's recommendation decreases as the level of health literacy increases and informing physician about personal health condition and consulting to a physician when a side effect occurs increase with the increasing level of health literacy. Many studies indicate that there is a relationship between the health literacy level and medication/treatment adherence and that as health literacy level rises, the frequency of use of healthcare services and hospitalization decreases $(15,23,24)$. Health literacy has been reported to be very important for patient safety and would reduce errors in medication use and improve adherence to therapy and affect access/use of health information (25). It is important that healthcare professionals use a clearer and more easily understandable language when providing health information to people with low level of health literacy and provide guidance for safe information sources. Since the study population consists of inpatients, they are in an older age group with higher risk conditions and with higher medication requirements. Healthcare institutions for inpatients should be used as a good opportunity to educate the society on RUD as the patients stay for longer periods in the hospital until their treatments are completed.

No relationship was found between some parameters of RUD such as using leftover drugs, storage in appropriate conditions, requesting prescription from physicians without being sick, making recommendation on medications to relatives/friends, self medication with antibiotics/vitamin supplementsand health literacy levels. In developing countries such as Turkey, cultural characteristics, previous experiences and common beliefs in the society can play a more effective role in such behaviour patterns.

\section{Conclusion}

The awareness for RUD is not sufficient in the study group. National campaigns are needed through the collaboration of professional groups such as medical and pharmaceutical organizations, international organizations, governments, non-governmental organizations, universities, educational institutions and the media sector to increase awareness on RUD. Additionally, improving patients' health literacy can reduce self-medication and improve adherence to therapy and therefore unnecessary and incorrect treatment processes can be avoided.

\section{Strengths and Limitations}

The strength of the present study is that it is the first study evaluating the relationship between RUD and health literacy in Turkey. Several limitations should be as, study carried out among hospitalized patients that the results can not be extrapolated to general population. This population constitutes a segment of the society that is highly more inclined to information about health. Thus the results might be better than the general. Another limitation might be memory factors that affect the responses.

\section{Acknowledgements}

The authors would like to thank the participants, hospital management for their efforts during research process and the medical school students while collecting data. The author(s) received no financial support. The authors declare that there is no conflict of interests.

\section{Ethics}

Ethical Committee Approval : Ethical approval was obtained from Ethical Committe of Adnan Menderes University, Non-Interventional Ethics Committee (2015/645).

Informed Consent: All patients included were informed about the study.

Peer-review: Externally and internally peerreviewed.

\section{Authorship Contributions}

Consept: F.A., B.D., Design: F.A., F.A., P.O., B.D., Data Collection or Processing: S.G.T., F.A., Analysis or interpretation: S.G.T., F.A., B.D., Literature research: S.G.T., B.D., Writing: F.A., P.O., B.D.

Conflict of Interest: The authors declare that they have no conflict of interest.

Financial Disclosure: The authors declare that they have no financial support. 


\section{References}

1. WHO (1985). The rational use of drugs: Report of the Conference of Experts Nairobi, 25-29 November 1985.

2. Mollahaliloğlu SAA, Özgülcü Ş, Öncül HG, Akıcı A. Hekimlerin Akılcı Reçete Yaklaşımı. R.A, editor. Ankara: T.C Sağlık Bakanlığı Refik Saydam Hıfzıssıhha Merkezi Başkanlığı Hıfzısıhha Mektebi Müdürlüğü, 2011.

3. Desalegn AA. Assessment of drug use pattern using WHO prescribing indicators at Hawassa University teaching and referral hospital, south Ethiopia: a cross-sectional study. BMC Health Serv Res 2013; 13: 170.

4. WHO (2016). http://www.who.int/medicines/areas/rational_ use/en/ , (accessed 20 September 2016)

5. İlhan MN, Aydemir Ö, Çakır M, Aycan S. Akılcı olmayan ilaç kullanım davranışları: Ankara'da üç ilçe örneği. Türkiye Halk Sağlığı Dergisi 2014; 12: 188-200.

6. WHO (1993). "How to investigate drug use in health facilities?", WHO Action Programme on Essential Drugs and International Network for the Rational Use of Drugs, 1993.

7. Bashrahil K. Indicators of rational drug use and health services in Hadramout, Yemen. East Mediterr Health J 2010; 16: 151-5.

8. Andrajati R, Tilaqza A, Supardi S. Factors related to rational antibiotic prescriptions in community health centers in Depok City, Indonesia. J Infect Public Health 2017; 10: 41-48.

9. Akıcı A, Uğurlu M. Ü, Gönüllü N, Oktay Ş, Kalaça S. Pratisyen hekimlerin akılcı ilaç kullanımı konusunda bilgi ve tutumlarının değerlendirilmesi. STED 2002; 11: 253.

10. Hatipoğlu S, Özyurt BC. Rational use of medicine in some family health centers in Manisa. TAF Prev Med Bull 2016; 15: 277-84.

11. Nayir T, Okyay RA, Yesilyurt H, Akbaba M, Nazlıcan E, Acık Y, et al. Assessment of rational use of drugs and self-medication in Turkey: A pilot study from Elazıg and its suburbs. Pak J Pharm Sci 2016; 29(4 Suppl): 1429-35.

12. Seçil Ö, Özbay OD, Aksakal FN, İlhan MN Aycan S. Attitudes During Illness And Drug Usage Habits Of Patients Attending To A University Hospital. TAF Prev Med Bull 2005; 4: 223-37.

13. Göçgeldi $E$, Uçar $M$, Açıkel $C H$, Türker $T$, Hasde $M$, Ataç $A$. Investigation of Frequency of Leftover Drugs at Home and Related Factors. TAF Prev Med Bull 2009; 8: 113-8.

14. HLS-EU Consortium (2012). Comparative Report on Health Literacy in Eight EU Member States The European Health
Literacy Survey. http://www.health-literacy.eu (last accessed 21 April 2016)

15. 15.Kickbusch IPJ, Apfel F, Agis T. Health Literacy: The Solid Facts, 1st edition. World Health Organisation Regional Office for Europe, Copenhagen, 2013.

16. T.C. Ministry of Health, Report on Reliability and validity of Turkish Health Literacy Scales, Okyay P, Abacıgil F Editors, Yayın No:1025, Anıl Reklam Matbaa Ltd. Şti., Ankara, 2016

17. Bilgili N, Karatay AG. Determination of Some Practices About Drug Consumption of Individuals Living In Sait Yazici Health Center Area. HUHEMFAD-JOHUFON 2005; 12: 39-48.

18. Ling Oh A1, Hassali MA, Al-Haddad MS, Syed Sulaiman SA, Shafie $A A$, Awaisu A. Public knowledge and attitudes towards antibiotic usage:a cross-sectional study among the general public in the state of Penang, Malaysia. J Infect Dev Ctries 2011; 5: 338-47.

19. Moraes AC, Delaporte TR, Molena-Fernandes CA, Falcão MC. Factors associated with medicine use and self medication are different in adolescents. Clinics (Sao Paulo) 2011; 66: 1149-55.

20. Donkor ES, Tetteh-Quarcoo PB, Nartey P, Agyeman IO. Selfmedication practices with antibiotics among tertiary level students in Accra, Ghana: a cross-sectional study. Int J Environ Res Public Health 2012; 9: 3519-29.

21. Parimi N, Pereira LMP, Prabhakar P. The general public's perceptions and use of antimicrobials in Trinidad and Tobago. Rev Panam Salud Publica 2002; 12: 11-8.

22. Abu Taha A, Abu-Zaydeh AH, Ardah RA, Al-Jabi SW, Sweileh WM, Awang R, et al. Public Knowledge and Attitudes Regarding the Use of Antibiotics and Resistance: Findings from a CrossSectional Study Among Palestinian Adults. Zoonoses and Public Health 2016; 63: 449-57.

23. Golin CE, Liu H, Hays RD, Miller LG, Beck CK, Ickovics J, et al. A prospective study of predictors of adherence to combination antiretroviral medication. J Gen Intern Med 2002; 17: 756-65.

24. Chew LD, Bradley KA, Flum DR, Cornia PB, Koepsell TD. The impact of low health literacy on surgical practice. Am J Surg 2004; 188: 250-3.

25. Davis TC, Wolf MS, Bass PF, Thompson JA, Tilson HH, Neuberger $\mathrm{M}$, Parker RM. Literacy and misunderstanding prescription drug labels. Ann Intern Med 2006; 19; 145: 887-94. 